\title{
THE ROLE OF AMBROSIA ARTEMISIIFOLIA ALLERGEN IN CANINE ATOPIC DERMATITIS
}

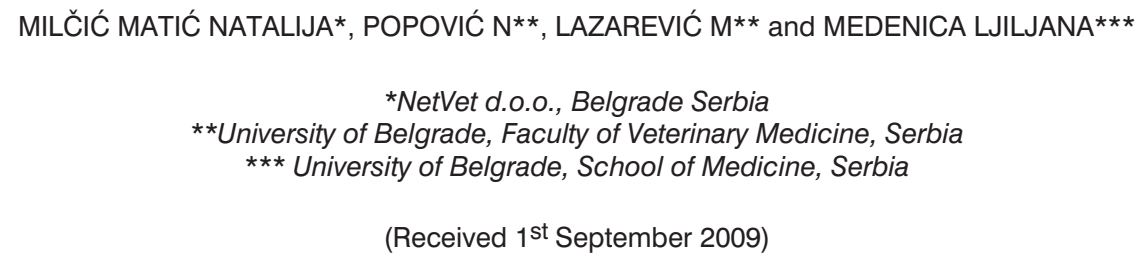

Pollens from Ambrosia species have a strong allergenic potential and they represent a complex mixture of at least 52 different antigens. This weed is widespread in Serbia and has a long pollination period (appr. 100 days). Pollens are present in very high concentrations during the pollination season (up to $300 \mathrm{pg} / \mathrm{m}^{3}$ of air). Fifty dogs with a clinical diagnosis of canine atopic dermatitis (CAD) and positive intradermal skin test (IDST) reactions to other environmental allergens were included in this study along with 30 dogs without clinical signs of CAD. Both groups were tested intradermally with Ambrosia artemisiifolia extract in concentration of $1000 \mathrm{PNU} / \mathrm{mL}$ (provided by "Institute of virology, vaccines and sera - Torlak"). We have found that Ambrosia extract was second most common allergen to yield positive intradermal test reactions just after house dust mites. The positive reaction of IDST was observed in $66 \%$ of the atopic dogs and in $10 \%$ of clinically healthy dogs. Dogs that had a positive reaction on intradermal skin test to Ambrosia pollens, mostly showed secondary skin lesions on the pads and perioral skin. In $88 \%$ of cases, Malassezia pachydermatis have been isolated from the skin in an increased number and $64 \%$ of dogs had otitis externa. These results indicate, that allergens from Ambrosia artemisifolia are of great importance in the etiopathogenesis of atopic dermatitis in dogs originating from the Belgrade region.

Key words: canine atopic dermatitis, Ambrosia artemisiifolia, ragweed, intradermal skin test (IDST), dogs

\section{INTRODUCTION}

Experience to date from the field of clinical veterinary medicine has shown that skin conditions are very common in clinical pathologies of dogs and cats (20$30 \%$ ). It is also believed that allergic disorders comprise approximately $50 \%$ of all dermatological cases (Picco et al., 2008). For example, in the USA, $15 \%$ of 55 million registered dogs, and probably a large number of cats, have allergic disorders (Hillier and Griffin, 2001). Among small animals the most prevalent form of allergic disorder is atopy. 
Atopy is a genetically-predisposed tendency to develop IgE-mediated allergy to environmental allergens and, in regard to dogs, it is most typically manifested as atopic dermatitis, and more rarely as atopic conjunctivitis and atopic rhinitis (Olivry et al., 2001). Atopic dermatitis is a genetically predisposed inflammatory and pruritic allergic skin disease with characteristic clinical features associated with IgE antibodies most commonly directed against environmental allergens (Halliwell, 2006).

The primary clinical manifestation of atopic dermatitis is pruritus and primary skin lesions, if existent, are present in the form of erythema. Secondary skin lesions are consequences of scratching, chronic skin inflammation and concurrent secondary pyodermia, and malassezia dermatitis (Fazakerley et al., 2009). Partial or complete alopecia is noticeable on the skin, as well as a redbrown staining of hair with saliva, excoriation, papules, pustules, dry and brittle hair, hyper-pigmentation, flaking and lichenification. These lesions are commonly located on sites of scratching, such as the face (muzzle, area surrounding the eyes), concave side of the ear lobe, dorsal and ventral areas of the paws, palmar sides of the carpal and tarsal joints, flexor parts of the joints of the extremities, axillary area, abdomen, groin, and the medial area of the thighs (DeBoer, 2001; Tarpataki and Papa, 2006).

Atopic dermatitis is a non curable skin disease, but it can be controlled. For this reason it is very important to, based on clinical symptoms, suppose the right diagnosis on time, and then confirm it using specific diagnostic methods, such as intradermal skin testing (IDST). IDST is the process of introducing antigens in the dermis of atopic patients to elicit a macroscopic hypersensitivity reaction (Olivry et al., 2001). Positive reactions are manifested as short term erythematous urticaria that appears during the first 30 minutes after allergen application. Its development is caused by the release of vasoactive mediators (histamine) from mastocytes leading to edema. This test can be used to determine which allergens induce hypersensitivity, making it then possible to avoid the incriminated allergens or, if this is not an option, immunotherapy can be considered. Allergen-specific immunotherapy is a practice of administering gradually increasing quantities of allergen extract to the allergic patient to ameliorate the symptoms associated with subsequent exposure to the causative allergen (Olivry et al., 2001).

Having said this, it is very important to, as precisely as possible; define all aspects of the complex clinical picture of atopic dermatitis in dogs. It is also important to determine the role of yeast fungi Malassezia pachydermatis in the clinical picture of atopic dermatitis, this being an unresolved question in human dermatology, as well.

Data from the dermatology ambulant of the Faculty of Veterinary Medicine in Belgrade shows that the number of atopic dogs has been increasing during the last 15 years. These data show that approx. 9\% of dogs in Belgrade have atopic conditions. The most common are those induced by allergens of house dust, house mites, and a mixture of weed pollens (Lazarevic et al., 1995). However, since 2000 the number of dogs with symptoms of allergic dermatitis most prevalent during late summer has significantly increased. By tracking the aeropalynological situation we have concluded that during this time of year 
ragweed is at the peak of its pollination season (www.sepa.sr.gov.yu). Ambrosia artemisiifolia belongs to the Asteraceae plant family, has an annual flowering period and reaches up to $150 \mathrm{~cm}$ in height. It was introduced into our country during the mid $19^{\text {th }}$ century with the seeds of red clover and since then has been spreading rapidly through this area, as up to $20 \mathrm{~km}$ per day during the flowering period (Stojsin et al., 2004). Ragweed pollen is a complex mixture of, up to now, 52 known antigens (Wopfner et al., 2005; Gadermaier et al., 2008). The highest air pollen concentration is present during late August and the beginning of September. It is believed that as little as 8 pollen grains of ragweed per one cubic meter of air is enough to induce allergic reactions in humans and animals, unlike other pollens where the limiting value is 30 pollen grains in a cubic meter per day (Gadermaier et al., 2008; Perovic et al., 2009).

\section{MATHERIALS AND METHODS}

This research was conducted on 50 dogs diagnosed with atopic dermatitis by intradermal skin testing. This test was also performed on 30 dogs without clinical manifestations of atopy. All tested dogs were from Belgrade, including the outer city regions.

\section{Clinical examination}

After taking detailed patient anamnesis and a general clinical examination, the skin was examined to determine the type and localization of changes. Each of these skin changes was measured and sketched into the patient examination forms. On top of everything, clinically visible skin changes on the paws, ear lobes, mouth area, and axillary area present in the form of secondary skin lesions were registered. These areas were chosen, in regard to the Prelaud criterion, as those with the most common skin lesion appearance sites in atopic dermatitis. In addition, each dog was checked for ear canal inflammation and a cytological ear swab smear was done. A complete clinical examination was also performed on healthy dogs, paying special attention to the state of skin and hair, as well as to the ear canal.

\section{Laboratory procedures}

Numerous laboratory procedures and diagnostic tests were performed on all dogs included in the study. Procedures such as checking for the presence of flees and scarification were done for differential diagnostic purposes, while cytological examinations of the skin and ear canal were performed to determine the degree to which the yeast fungi Malassezia pachydermatis was present on the skin of atopic dogs and check for the presence of otitis externa. Clinically healthy dogs were tested for the presence of flee feces and Malassezia pachydermatis on the skin and ear canal cytological swab smears were done.

Cytological skin tests for the presence of Malassezia pachydermatis

Samples from tested dogs were taken from three predetermined skin areas: interdigital area (between the third and fourth digit of the right front leg), corner of the mouth, and the axillary area of both legs. Hairs were removed from the 
interdigital area before sample collection. Skin samples were taken by a sterile cotton swab stick which was rubbed for 5 seconds on the chosen skin area. Material from the cotton swab was then, with gentle rotating movements, transferred to a clean microscope slide. The samples were heat fixed on a flame for 2 seconds and then colored with methylene blue. After 10 minutes methylene blue was removed, the sample air dried and examined under an immersion microscope objective after the addition of an immersion oil droplet. Samples with more than 5 Malassezia organisms in the field of view were considered to be positive. The same set of skin samples were taken from clinically healthy dogs and these samples were also treated by the above mentioned method.

\section{Cytological examination of the external ear canal}

A cytological swab smear of the external ear canal was done for all examined dogs. The sample was taken by a sterile cotton swab stick that was placed into the horizontal area of the ear canal and the collected material was transferred onto a microscope slide with rotating movements. Heat fixation of the samples was done for 2 seconds on a flame, followed by methylene blue coloring, air drying and addition of an immersion oil droplet. The samples were then examined under an immersion microscope objective. Depending on the examination results, the samples were classified into the following groups: those with only Malassezia infections, those with only bacterial infections, and those with a mixed infection. Samples found to have a rod-like bacteria present were sent to a microbiological laboratory where biograms and antibiograms were performed. The same procedure was done on samples originating from healthy dogs.

\section{Intradermal skin testing}

IDST was performed by the standard method on 50 dogs clinically suspected for atopy and on 30 clinically healthy dogs.

Pharmacological therapy was discontinued in all dogs for the appropriate time period before testing. This time period for glucocorticoid injections is 8 weeks, oral and topical ingestion - 3 weeks, antihistamines - 10 days, ketoconazole - 3 weeks, and for drugs and food containing omega-3/ omega-6 fatty acids -10 days before intradermal testing.

Before testing, hair was removed from the lateral thorax area of the dogs by an electrical hair trimmer with cartridge number 40 and the skin area of the intended allergen application sites (spaced $3 \mathrm{~cm}$ from each other) was marked with a waterproof marker. Testing was performed on nonsedated animals laid on the table in a latero-lateral position. Intradermal testing with seasonal and non seasonal allergens was performed with standard water solutions of allergens manufactured by the Institute of virology, vaccines and sera, Torlak.

Intradermal testing was done with the following 12 allergens, with a positive ad negative control: House dust $250 \mathrm{PNU} / \mathrm{mL}$, Dermatophagoides $250 \mathrm{PNU} / \mathrm{mL}$, Grass pollen mixture $1000 \mathrm{PNU} / \mathrm{mL}$, Tree pollen mixture $1000 \mathrm{PNU} / \mathrm{mL}$, Weed pollen mixture $1000 \mathrm{PNU} / \mathrm{mL}$, Mold pollen mixture $500 \mathrm{PNU} / \mathrm{mL}$, Bacterial allergen mixture $1000 \mathrm{PNU} / \mathrm{mL}$, Insect allergen mixture $1000 \mathrm{PNU} / \mathrm{mL}$, Cigarette smoke $1000 \mathrm{PNU} / \mathrm{mL}$, Feathers mixture $500 \mathrm{PNU} / \mathrm{mL}$, Bed dust $1000 \mathrm{PNU} / \mathrm{mL}$, Ragweed 
$1000 \mathrm{PNU} / \mathrm{mL}$, Histamine phosphate 1: $100000 \mathrm{w} / \mathrm{v}$ (positive control), $0.9 \%$ saline solution (negative control).

For the intradermal application of the allergens, as well as the positive and negative controls, a $1 \mathrm{~mL}$ syringe with a $26 \mathrm{G}(0.5 \mathrm{~mm})$ needle was used. $0.05 \mathrm{~mL}$ of prepared allergen extracts and controls were intradermally applied into the marked skin sites. Results of the intradermal testing were determined after 15 minutes, and during that time dogs remained on the examination table so we could act in case of unwanted reactions and also to prevent the dogs from scratching and licking the skin at the application site.

After 15 minutes the diameters of skin changes were measured with a seethrough ruler and the reactions were graduated. A reaction with the same dimensions as the negative control was assigned the value 0 , and a reaction with the same dimensions as the histamine control was assigned the value +4 . Reactions assigned values $+1,+2$, and +3 comprise $1 / 4,1 / 2$, and $3 / 4$ of the difference in dimensions between the positive and the negative control. Reactions with the value of +2 and above were considered positive.

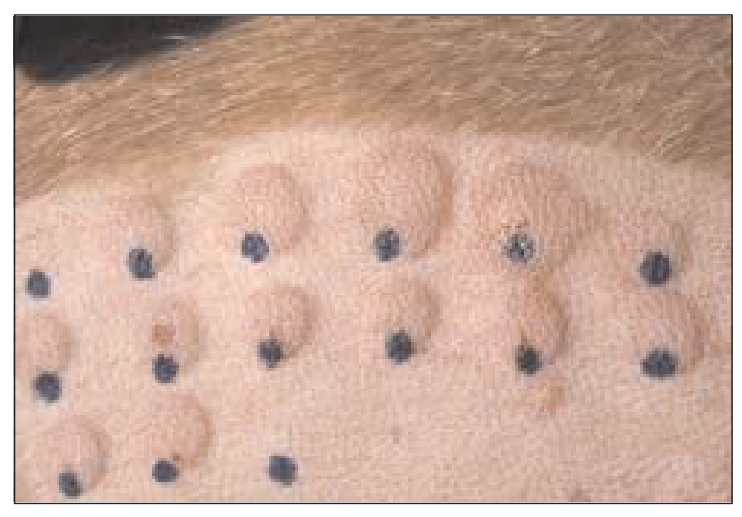

Figure 1. Positive reactions on intradermal skin test

\section{RESULTS}

\section{Clinical examination}

In this study attention was directed towards the four skin sites were secondary lesions from atopic dermatitis in dogs are most prevalent: the paws, mouth area, axillary region and the ear lobes. In Ambrosia allergic dogs, changes in the paw area were present in 26 dogs $(79 \%)$ in the form of papules and pustules, red-brown staining of hair with saliva and alopecia with skin edema. In 23 dogs $(70 \%)$ changes on the skin around the mouth were registered, consisting of skin redness, alopecia and lichenification. In 21 dogs (64\%) changes on the skin of the axillary region were present in the form of hyperpigmentation and skin lichenification. In 17 dogs (51\%) changes on the skin of at least one ear lobe were noticed, with symptoms of redness, alopecia and skin flaking. 
Cytological skin tests for the presence of Malassezia pachydermatis

A higher amount of Malassezia pachydermatis was found on the skin in $88 \%$ of dogs allergic to ragweed pollen. On the skin surrounding the mouth an increase of this fungus was shown in $60 \%$ of the dogs, in the axillary area $28 \%$, and in the interdigital area in $26 \%$ of the dogs. All dogs that had red-brown staining of the hair with saliva, also had a higher amount of Malassezia in their samples. All examined dogs of the West Highland white terrier breed were found to have a higher amount of Malassezia in their samples. In the group of clinically healthy dogs a higher amount of Mallasezia pachydermatis on the skin in 33\% of dogs.

Cytological examination of the ear canal

In 21 dogs allergic to ragweed pollen an inflammation of the external ear canal was diagnosed. From the group that had changes on their ear lobes 15 dogs were diagnosed with otitis externa, while 6 dogs had inflammation of the ear canal but without visible changes on their ear lobes.

During microscopic examination of the cytological swab smears of the ear canal the following results were noted: 2 dogs had only Malassezia infections; 14 dogs had a mixed infection with Malassezia and cocci bacteria; in 3 dogs only a cocci bacterial infection was present, and 2 dogs had rod bacterial infections.

In the group of clinically healthy dogs inflammation of the ear canal was diagnosed in one dog of the Cocker Spaniel breed, and this was a mixed (Malassezia and cocci bacteria) infection.

\section{Intradermal testing}

In our study 12 allergens were used, and Table 1 shows the number and percentage of dogs, clinically suspected for atopic dermatitis and clinically healthy, which showed a positive reaction in intradermal testing to specific allergens.

Table 1. Results of IDST in 50 clinically suspected dogs for atopic dermatitis and 30 clinically healthy dogs

\begin{tabular}{|l|c|c|}
\hline Allergen extract & $\begin{array}{c}\text { Dogs with atopic } \\
\text { dermatitis symptoms }\end{array}$ & Clinically healthy dogs \\
\hline \hline House dust mites & $34(68 \%)$ & $4(13 \%)$ \\
\hline House dust & $30(60 \%)$ & $2(7 \%)$ \\
\hline Grass pollen mix & $14(28 \%)$ & $1(3 \%)$ \\
\hline Weed pollen mix & $27(54 \%)$ & $1(3 \%)$ \\
\hline Tree pollen mix & $8(16 \%)$ & 0 \\
\hline Insects mix & $13(26 \%)$ & $3(10 \%)$ \\
\hline Ambrosia artemisiifolia & $33(66 \%)$ & 0 \\
\hline Moulds mix & $21(42 \%)$ & $1(3 \%)$ \\
\hline Tabacco smoke & $8(16 \%)$ & $1(3 \%)$ \\
\hline Bacterial & $19(38 \%)$ & $1(3 \%)$ \\
\hline Bed dust & $12(24 \%)$ & \\
\hline Feathers mix & $5(10 \%)$ & \\
\hline
\end{tabular}


Ragweed pollen is the second most frequent positive reaction inducing allergen in examined dogs (Table 1 ). In the group of clinically suspect atopic dogs a positive reaction to ragweed pollen was registered in 33 dogs $(66 \%)$ and in the group of clinically healthy dogs in $3(10 \%)$. Table 2 shows the correlation between the appearance of certain clinical symptoms, age at which the first clinical symptoms appeared, time of year the symptoms appear, place and conditions in which the dog is kept and the positive reaction to allergens from ragweed pollen.

\section{DISCUSSION}

As mentioned before, according to the Prelaud criteria, clinically visible changes in atopic dermatitis in dogs are most commonly noticed in the form of secondary skin lesions on the paws, ear lobes, skin surrounding the mouth, and axillary area (Prelaud et al., 1998; Picco et al., 2008; Martins et al., 2008). Based on the results of our research, in ragweed allergic dogs, these changes are predominantly found on the skin of the paws (79\%), followed by the skin surrounding the mouth (70\%), and axillary region (64\%) and somewhat less often on the skin of the ear lobes (51\%). Licking and chewing of the paws and changes induced in this way on the paw skin are considered characteristic for atopic dermatitis, and there is a hypothesis stating that this is a predilection site for the percutaneous resorption of aeroallergens (Olivry and Hill, 2001; Pucheu-Haston et al., 2008; Marsella and Girolomoni, 2009). In most dogs that had the mentioned changes a red-brown staining of the hair was noticed. This change in hair color is due to licking and staining of the hair with porphyrin from saliva. Based on the obtained results we can conclude that the Prelaud criterion is a good diagnostic procedure for clinical diagnosis of suspected atopic dermatitis in dogs.

Our research showed a higher amount of Malassezia pachydermatis in $88 \%$ ragweed allergic and in 33\% percent of clinically healthy dogs. Literature data concerning the presence of this fungi in higher amounts on the skin of atopic dogs shows that it has been diagnosed in a varied percentage, from 38\% (Zur et al., 2002) to $72 \%$ of dogs (Nardoni et al., 2004). The relatively high percentages obtained in our research are explained by the fact that our study was conducted in a damp and warm period of the year, which stimulates the development of Malassezia on the skin (Scott et al., 2001). The precise mechanism that allows for the excessive reproduction of this fungus is not yet fully known, but it is believed that it commonly appears in skin diseases that induce alterations in host defense mechanism and changes in the cutaneous microclimate (Chen et al., 2005). In atopic dermatitis impairment of the epidermal barrier is present and alterations in the immune system can also stimulate the proliferation of this fungus (Marsella and Girolomoni, 2009, Matousek et al, 2002). A higher amount of Malassezia on the skin leads to an increase of pruritus, since this fungi releases proteases that are considered mediators of itching of the free nerve endings in the skin (Mason, 1991). Additionally, the disrupted epidermal barrier could permit the skin immune system to be exposed to Malassezia antigens and products, eliciting inflammatory and/or hypersensitivity reactions (Habibah et al., 2005). It is still not known why 
the increase in the amount of Malassezia on the skin doesn't appear in all dogs with atopic dermatitis (Chen et al., 2005).

For healthy dogs, the percentages noted in literature concerning the presence of this fungus in higher amounts also vary: from $32 \%$ (White et al., 1988) to $52 \%$ (Nardoni et al., 2004). In these types of studies, a same breed control group of dogs kept in the kennels is usually used. Environmental and poor living conditions are a good predisposition for the development of Malassezia. In our research group the clinically healthy dogs were animals living as pets in households, which we believe to have caused a lower percentage (33\%) of registered Malassezia on the skin of the healthy dog group.

On the skin surrounding the mouth an increase of this fungus was shown in $60 \%$ of the dogs, in the axillary area $28 \%$, and in the interdigital area in $26 \%$ of the dogs. It is interesting to note that in the healthy dog group there is also a higher amount of Malassezia in the area surrounding the mouth, and this is consistent with literature data (Bond et al., 1995; Kennis et al., 1996; Nardoni et al., 2007). It is presumed that the saliva induced wetness of this area, suggesting that increased cutaneous humidity favors yeast growth. Since our research followed clinically visible changes on the skin of certain body regions, and that swabs were cytologically examined, we noticed that Malassezia appears in a much higher percentage on skin that has already suffered damage. Presumably, the scratching and licking leads to breaks in the epidermal barrier and increased moistening of the skin, which can stimulate proliferation of Malassezia.

We have also noticed a breed predisposition for the excessive development of this fungus. In all dogs of the West Highland white terrier breed, on all three examined locations, a higher amount of Malassezia was found. Also, a higher amount of Malassezia was noticed on the skin of Golden retrievers, and somewhat less on the skin of Labrador retrievers. There is data in literature also stating the predisposition of West Highland white terriers, as well as Basset hounds, Dachshunds and Cocker Spaniels for Malassezia over growth (Scott et al., 2001; Plant et al., 1992; Bond et al., 1996; Picco et al., 2008).

We diagnosed a higher amount of this fungus on the skin of dogs examined during the rainy month of August, than of those examined during the dry and warm July. It is believed that warm and humid weather stimulates proliferation of Malassezia (Scott et al., 2001).

Otitis externa has been diagnosed in $64 \%$ of dogs allergic to Ambrosia pollen, and of these the highest number had changes on the skin of the ear lobe. In the cytological swab smears of the ear canal the most frequent result was a mixed infection: cocci bacteria and Malassezia fungi in a higher amount. According to data from literature, Otitis externa appears in the commencing phase of illness in $45 \%$ of atopic dogs. In later phases this percent goes up to even $80 \%$ (Scott et al., 2001; Muse et al., 1996; Angus, 2004), and as the only symptom of atopic dermatitis it appears in 5\% of affected dogs (Fraser et al., 2008). Otitis externa in atopic dermatitis can appear as a secondary development, induced by self inflicted wounds or when the hypersensitivity reaction also includes the skin of the external ear canal (Scott et al., 2001; Saridomichelakis et al., 2007). Various lesions can be found on the skin of the external ear canal including erythema, 
oedema, lichenification, erosions and ulcers, and exudate is not present in higher amounts at the early stage of the illness (Saridomichelakis, 2008; Cole, 2004). Secondary manifestations include proliferation of Malassezia and bacteria, which contributes to the worsening of symptoms and a clinically manifested otitis externa (Ginel et al., 2002).

In our research we used 12 allergens in recommended concentrations (Hensel et al., 2004). Most of the dogs were multisensitive (98\%), and have positive reactions to both seasonal and nonseasonal allergens (64\%). Literature data confirms our findings (Zur et al., 2002; Nødtvedt et al., 2006).

The most commonly encountered positive test results were against housedust mites (68\%). Also, literature data confirms a strong reaction to this allergen $(47-80 \%)$ when applied in the concentration of $250 \mathrm{PNU} / \mathrm{mL}$, which we used (Carloti et al., 1994; Zur et al., 2002; Tarpataki et al., 2006; Espino et al., 2008; Chanthick et al., 2008; Sung et al., 2009). To our knowledge, there is only one report stating that house mite allergen is not a common cause of atopic dermatitis in dogs (Koch et al., 1994). Also, the highest number (13\%) of clinically healthy dogs showed a reaction to this allergen, indicating the strong irritating effect of this allergen extract (Reedy et al., 1997). This percent is much higher in literature, ranging from 36\% (Hillier et al., 2000) to $75 \%$ (Halliwell et al., 1998), but in these studies were used a much higher concentration of this allergen.

A reaction to house dust allergen was noticed in $60 \%$ of dogs and this data is concurrent with literature (Carloti et al., 1994; Zur et al., 2002; Chanthick et al., 2008; Sung et al, 2009). Mixtures of grass pollens, tree pollens and weed pollens were used in our study. Although most authors agree that false negative results are possible when using such mixtures, it is quite common in intradermal testing to first perform tests with a mixture of allergens, and to follow with tests on individual allergens from the mixture that gave a positive reaction. Results obtained for pollen mixtures of grass and trees concur with those from literature, while those obtained for allergens from weed pollens have higher values $(54 \%$ of dogs) (Zur et al., 2002; Sung et al., 2007; Chanthick et al., 2008).

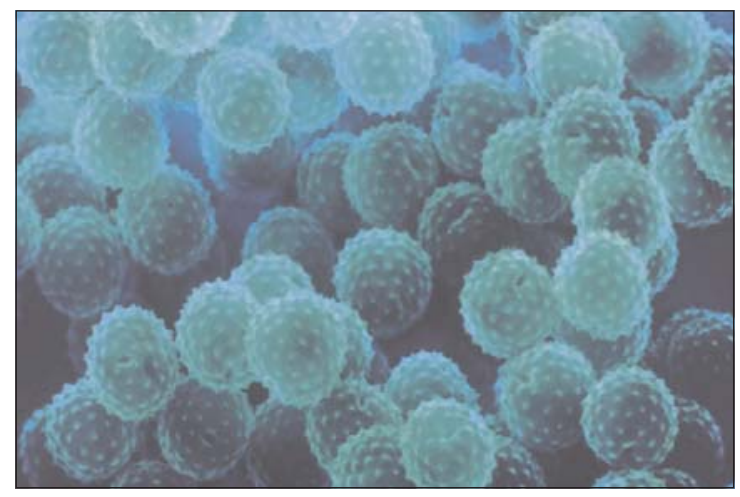

Figure 2. Ragweed pollen 
Positive reaction to ragweed (Ambrosia artemisiifolia) allergen was registered in 33 dogs $(66 \%)$, making the pollen of this plant the second most frequent positive reaction inducer in examined dogs. These results are not surprising, considering that the pollen of this plant has strong allergenic properties, is comprised of, up till now, 52 discovered antigens and that only 8 pollen grains per cubic meter are enough to cause an allergic reaction in humans and animals (Wopfner et al., 2005; Gadermaier et al., 2008; Perovic et al., 2009). This plant is widespread in the region of East-Central Europe, particularly in Hungary, Serbia, Croatia, Slovakia and the Czech Republic (Gadermaier et al., 2008; Burbach et al., 2009). Also, data from our country shows that highest concentrations is in Vojvodina and especially in the city of Belgrade, with approximately 15 millions of this plant (Kovacevic, 2003; Mitrovic Josipovic, 2009).

During the last few years, we have noticed an increase in the number of dogs with intensive pruritus in late summer and the beginning of autumn, when Ambrosia is in high pollination. Our colleagues allergologists researching human allergy symptoms have also noticed that a significant number of Belgrade residents, like residents of USA, have severe respiratory symptoms, followed by shortness of breath at this time of the year. Unfortunately, research data concerning the number of ragweed pollen allergic people in Belgrade has not yet been published. Also, in veterinary medicine, there are little published data concerning the frequency of positive reactions to this allergen (Youn et al., 2002; Zur et al., 2002). All authors from USA agree that ragweed is the most significant weed pollen allergen, and underline the strong allergenic effect of this plant (Reedy et al., 1997; Scott et al, 2001; Hillier, 2001).

According to our research, in 24 dogs (73\%) that had a positive reaction to ragweed pollen a positive reaction to weed pollen mixture was also noticed. Only 3 dogs had a positive reaction to the weed pollen mixture, and are probably allergic to one of the remaining 5 weeds present in this mixture. However, in 9 dogs $(27 \%)$ we noted a positive reaction to ragweed pollen, while the reaction to the weed pollen mixture was negative. Literature data shows a correlation between individual allergens and group allergens that varies from 60 to $75 \%$ (Nesbitt et al., 1984; Willemse, 1986). Group allergens are made by combining equal amounts of each ingredient. In a $1 \mathrm{~mL}$ mixture of 6 allergens (like the one we used as a weed pollen mixture) that has a concentration of $1000 \mathrm{PNU} / \mathrm{mL}$, there are $170 \mathrm{PNU}$ of each allergen. Since we inject $0.05 \mathrm{~mL}$ of allergen extract solution for intradermal testing; only 8.5 PNU will be applied of each allergen, instead of the 50 PNU that are applied when using individual allergens. The lower concentration of individual allergens in a mixture often induces negative reactions, and for this reasons most allergologists recommend using only individual allergen extracts in intradermal testing (Hillier and Deboer, 2001).

When we compare our results with those from 1995 (Lazarevic et al., 1995), it is noticeable that weed pollen allergy appeared in much lower percentages $(1.75 \%)$. It should be noted that at that time testing wasn't done specifically for ragweed pollen. The presumption is that ragweed has spread in our area in the 
Acta Veterinaria (Beograd), Vol. 60, No. 2-3, 183-196, 2010.

Milčić Matić Natalija et al.: The role of Ambrosia artemisiifolia

allergen in canine atopic dermatitis

last 10 years, and most likely other weeds as well, thus leading to a higher number of allergic dogs.

In dogs that had a positive reaction to ragweed pollen in intradermal testing, changes on the skin were usually present on the paws $(79 \%)$ and around the mouth (70\%). A higher amount of Malassezia was found in $88 \%$ of dogs, and otitis externa in $64 \%$. First clinical symptoms of the illness appeared before the third year of age (91\%), and were present during the whole year in $66 \%$ of dogs (Table 2).

Other allergens used in intradermal testing gave positive reactions in percentages similar to those stated in literature.

Table 2. Correlation between named parametars and positive reaction on ragweed pollen

\begin{tabular}{|l|c|c|}
\hline & No of dogs & \% of dogs \\
\hline \hline Otitis externa & 21 & 64 \\
\hline Affected paws & 26 & 79 \\
\hline Malassezia pachydermatis & 29 & 88 \\
\hline Affected pinna & 17 & 51 \\
\hline Affected mouth & 23 & 70 \\
\hline Affected axillae & 21 & 64 \\
\hline I clin. symptom $<1 \mathrm{~g}$ & 9 & 27 \\
\hline I clin. symptom 1-3 g & 21 & 64 \\
\hline I clin. symptom $>3 \mathrm{~g}$ & 3 & 9 \\
\hline Seasonal symptoms & 11 & 33 \\
\hline Unseasonal symptoms & 22 & 66 \\
\hline Indoor living & 26 & 79 \\
\hline Outdoor living & 7 & 21 \\
\hline
\end{tabular}

These results indicate, that allergens from Ambrosia artemisifolia are of great importance in the etiopathogenesis of atopic dermatitis in dogs originating from the Belgrade region.

Address for correspondence:

MSc Natalija Milcic Matic, PhD student

Faculty of Veterinary Medicine

University of Belgrade

Belgrade, Serbia

Bulevar oslobodjenja 18

E-mail: natalijamm@gmail.com 


\section{REFERENCES}

1. Angus JC, 2004, Otic cytology in health and disease, Vet Clin North Am Small Anim Pract, 34, 411-24

2. Bond R, Ferguson EA, Curtis CF, Craig JM, Lloyd DH, 1996, Factors associated with elevated cutaneous Malassezia pachydermatis populations in dogs with pruritic skin disease, J Small Anim Pract, 37, 103-7.

3. Bond R, Saijonmaa-Koulumies $L E$, Lloyd DH, 1995, Population sizes and frequency of Malassezia pachydermatis at skin and mucosal sites on healthy dogs, J Small Anim Pract, 36, 4, 147-50.

4. Burbach GJ, Heinzerling LM, Rçhnelt C, Bergmann K-C, Behrendt H, Zuberbier T, 2009, Ragweed sensitization in Europe - GA2LEN study suggests increasing prevalence, Allergy, 64, 4, 664-5.

5. Carlotti $D N$, Costagent $F, 1994$, Analysis of positive skin tests in 449 dogs with allergic dermatitis, Eur $J$ Comp An Pract, 4, 42-59.

6. Chanthick C, Anaman S, Buathet $K, 2008$, The prevalence of positive intradermal allergy tests in 114 dogs with atopic dermatitis in the Bangkok metropolis, Thailand, Vet Immunol Immunopathol, $126,256-62$.

7. Cole LK, 2004, Otoscopic evaluation of the ear canal, Vet Clin North Am Small Anim Pract, 34, 397410.

8. DeBoer DJ, 2001, The ACVD task force on canine atopic dermatitis (15): fundamental concepts in clinical diagnosis, Vet Immunol Immunopathol, 81, 271-6.

9. Fazakerley J, Nuttall T, Sales D, Schmidt V, Stuart D, Carter C et al., 2009, Staphylococcal colonization of mucosal and lesional skin sites in atopic and healthy dogs, Vet Dermatol, 20, 179-84.

10. Fraser MA, McNeil PE, Girling SJ, 2008, Prediction of future development of canine atopic dermatitis based on examination of clinical history, J Small Anim Pract, 49, 128-32.

11. Gadermaier G, Wopfner N, Wallner M, Egger M, Didierlaurent A, Regl G et al., 2008, Array-based profiling of ragweed and mugwort pollen allergens, Allergy, 63, 1543-9.

12. Ginel PJ, Lucena R, Rodriguez JC, Ortega J, 2002, A semiquantitative cytological evaluation of normal and pathological samples from the external ear canal of dogs and cats, Vet Dermatol, $13,151-6$

13. Goicoa A, Espino L, Rodriguez I, Puigdemont A, Brazis P, Rejas J, 2008, Importance of house dust and storage mites in canine atopic dermatitis in the geographic region of Galicia, Spain, Acta Vet Hung, 56, 2, 163-71.

14. Habibah A, Catchpole B, Bond R, 2005, Canine serum immunoreactivity to M. pachydermatis in vitro is influenced by the phase of yeast growth, Vet Dermatol,16, 147-52.

15. Halliwell $R, 2006$, Revised nomenclature for veterinary allergy, Vet Immunol Immunopathol, 114, 207-8.

16. Halliwell REW, Gilbert SM, Lian TM, 1998, Induced and spontaneous IgE antibodies to Dermatophagoides farinae in dogs and cats: Evidence of functional heterogeneity of IgE. Vet Dermatol, 9, 179.

17. Hensel P, Austel M, Medleau L, Zhao Y, Vidyashankar A, 2004, Determination of treshold concentrations of allergens and evaluation of two different histamine concentrations in canine intradermal testing, Vet Dermatol, 15, 304-8.

18. Hillier A, Griffin CE, 2001, The ACVD task force on canine atopic dermatitis (1): incidence and prevalence, Vet Immunol Immunopathol, 81, 147-51.

19. Hillier A, Kwochka KW, Riester LR, 2000. Reactivity to intradermal reaction of extracts of Dermatophagoides farinae, Dermatophagoides pteronyssinus, house dust mite mix and house dust in dogs suspected to have AD: 115 cases (1996-1998), J Am Vet Med Assoc, 217, 536-40.

20. Hillier A, DeBoer DJ, 2001. The ACVD task force on canine atopic dermatitis: intradermal testing, Vet Immunol Immunopathol, 81, 289-304.

21. Kennis RA, Rosser Jr EJ, Olivier NB, Walker RW, 1996, Quantity and distribution of Malassezia organisms on the skin of clinically normal dogs, J Am Vet Med Assoc, 208, 1048-51.

22. Koch HJ, Peters S, 1994, 207 intracutaneous tests in dogs with suspicion of atopic dermatitis. Kleintierpraxis, 39, 25-36. 
23. Lazarevic G, Milcic N, Popovic N, 1995, Atopijski dermatitis pasa, Zbornik plenarnih referata i kratkih sadrzaja, 120-133, 23-26 maj, Beograd 1995.

24. Marsella R, Girolomoni G, 2009, Canine Models of Atopic Dermatitis: A Useful Tool with Untapped Potential, Review, J Invest Dermatol, 129, 2351-7.

25. Martins LML, Valdevira AG, Lopez JR, 2008, Allergy diagnosis - an application to dog, Exp Pathol Health Sci, 2, 51-60.

26. Mason KV, Evans AG, 1991, Dermatitis associated with Malassezia pachydermatis in eleven dogs, $J$ Am Anim Hosp Assoc, 27, 13-20.

27. Matousek JL, Campbe/l KL, 2002, Malassezia dermatitis, Compendium on Continuing Education for the Practicing Veterinarian, 24, 224-32.

28. Mitrovic Josipovic M, 2009, Izvestaj o stanju zivotne sredine u Republici Srbiji. Agencija za zastitu zivotne sredine, www.sepa.gov.rs.

29. Muse R, Griffin CE, Rosenkrantz WS, 1996, The prevalance of otic manifestations and otitis externa in allergic dogs, Proceedings of Annual Members Meeting of American Academy of Veterinary Dermatologists - American College of Veterinary Dermatologists, 12, 33.

30. Nardoni S, Dini M, Taccini F, Mancianti F, 2007, Occurrence, distribution and population size of Malassezia pachydermatis on skin and mucosae of atopic dogs, Vet Microbiol, 122, 172-7.

31. Nardoni S, Mancianti F, Corazza M, Rum A, 2004. Occurence of Malassezia species in healthy and dermatologically diseased dogs, Mycopathology, 157, 383-8.

32. Nødtvedt A, Bergvall K, Emanuelson U, Egenvall A, 2006, Canine atopic dermatitis: validation of recorded diagnosis against practice records in 335 insured Swedish dogs, Acta Vet Scand, 48,

33. Olivry T, DeBoer DJ, Griffin CE, Halliwell RE, Hill PB Hiller A et al., 2001, The ACVD task force on canine atopic dermatitis (Editorial): forewords and lexicon, Vet Immunol Immunopathol, 81 , 143-6.

34. Olivry T, Hill PB, 2001, The ACVD task force on canine atopic dermatitis (IX): the controversy surrounding the route of allergen challenge in canine atopic dermatitis, Vet Immunol Immunopathol, 81, 219-25.

35. Perovic I, Milovanovic M, Stanic D, Burazer L, Petrovic D, Milcic-Matic N et al., 2009, Allergenicity and immunogenicity of the major mugwort pollen allergen Art $\mathrm{v} 1$ chemically modified by acetylation, Clin Exp Allergy, 39, 3, 435-46.

36. Picco F, Zini E, Nett C, Naegeli C, Bigler B, Rüfenacht $S$ et al, 2008, A prospective study on canine atopic dermatitis and food induced allergic dermatitis in Switzerland, Vet Dermatol, 19, $150-5$.

37. Plant JD, Rozenkratz WS, Griffin CE, 1992, Factors associated with and prevalence of high Malassezia pachydermatis numbers on dog skin, J Amer Vet Asoc, 201, 879-82.

38. Prelaud P, Guagere E, Alhaidari Z, Faive N, Heripre D, Gayerie A, 1998, Reevaluation of diagnostic criteria of canine atopic dermatitis, Rev Med Vet, 149, 1057-64.

39. Pucheu-Haston CM, Jacksonw HA, Olivry T, Dunston SM, Hammerberg B, 2008, Epicutaneous sensitization with Dermatophagoides farinae induces generalized allergic dermatitis and elevated mite-specific immunoglobulin E levels in a canine model of atopic dermatitis, Clin Exp Allergy, 38, 667-79.

40. Reedy LM, Miller WH, Williemse T, (Eds.), 1997, Allergic Skin Disease of the Dog and Cat, $2^{\text {nd }}$ Edition. W.B. Saunders, London, UK.

41. Saridomichelakis $M N, 2008$, Diagnostic approach to otitis, In Proceedings from $6^{\text {th }}$ World Congress of Veterinary Dermatology, Hong Kong, 87-94.

42. Saridomichelakis MN, Farmaki R, Leontides LS, Koutinas AF, 2007, Aetiology of canine otitis externa: a retrospective study of 100 cases, Vet Dermatol, 18, 341-7.

43. Scott DW, Miller WH, Griffin CE, 2001, Malassezia dermatitis IN. Small Animal Dermatology, $6^{\text {th }}$ Edition. W.B.Saunders, Philadelphia, 363-74.

44. Stojsin V, Bagi F, Balas F, Tomic Z, 2004, Potencijalni patogeni Ambrosia artemisiifolia u bioloskoj borbi, Zbornik radova, V kongres zastite bilja, Zlatibor, 212-3.

45. Sung TY, Huang HP, 2009, The Incidence of Positive Intradermal Skin Test Reactions in Dogs with Atopic Dermatitis, J Vet Clin Sci, 2, 31-6. 
46. Tarpataki N, Papa K, 2006, Prevalence and features of canine atopic dermatitis in Hungary, Acta Vet Hung, 54, 353-66.

47. White SD, Bordeau P, Blumstein P, Ibish C, Scott KV, Salman MD, Chapman PL, 1998, Comparison via cytology and culture of carriage of Mallasezia pachydermatis in atopic and healthy dogs. In: Kwocka, KW et al (Eds): Advances in Veterinary Dermatology III. Butteworth Heinemann.

48. Wopfner N, Gadermaier G, Egger M, Asero R, Ebner C, Jahn-Schmid B et al., 2005, The spectrum of Allergens in Ragweed and Mugwort Pollen, Int Arch Allergy Immunol, 138, 337-46.

49. Wopfner N, Gadermaier G, Egger M, Asero R, Ebner C, Jahn-Schmid B et al., 2005, The Spectrum of Allergens in Ragweed and Mugwort Pollen, Int Arch Allergy Immunol, 138, 337-46.

50. Youn HY, Kang HS, Bhang DH, Kim MK, HwangCY, Han HR, 2002, Allergens Causing Atopic Diseases in Canine, $J$ Vet Sci, 3, 4, 335-41.

51. Zur G, Ihrke PJ, White SD, Kass $P H, 2002$. Canine atopic dermatitis: a retrospective study of 266 cases examined at the University of California, Davis, 1992-1998, Vet Dermatol, 13, 89-102.

\title{
ZNAČAJ ALERGENA BILJKE AMBROSIA ARTEMISIIFOLIA U ETIOPATOGENEZI ATOPIJSKOG DERMATITISA PASA
}

\author{
MILČIĆ MATIĆ NATALIJA, POPOVIĆ N, LAZAREVIĆ M i MEDENICA LJILJANA
}

\section{SADRŽAJ}

Polen ambrozije ima jaka alergijska svojstva i sastoji se od kompleksne mešavine od do sada poznatih 52 antigena. Ova korovska biljka je znatno rasprostranjena u Srbiji i i ima dugačak period polinacije od prosečno 100 dana. Polen je prisutan u izrazito visokim koncentracijama tokom avgusta i septembra ide i do 300 polenovih zrna u $\mathrm{m}^{3}$ vazduha. Ovim ispitivanjem obuhvaćeno je 50 pasa kod kojih je dijagnostikovan atopijski dermatitis na osnovu kliničkih simptoma i pozitivne reakcije na intradermalnom testu, kao i 30 pasa bez klinički manifestnih simptoma atopijskog dermatitisa. Kod obe grupe pasa uradjeno je intradermalno testiranje standardnim rastvorima proizvođača Instituta za imunologiju i virusologiju Torlak, kao i vodenim rastvorom alergena ambrozije u koncentraciji $1000 \mathrm{PNU} / \mathrm{ml}$. U našem ispitivanju polen ambrozije predstavlja drugi alergen po učestalosti pozitivne reakcije na intradermalnom testu kod ispitivanih pasa, odmah posle kućnih grinja. Pozitivna reakcija zabeležena je kod 66\% pasa iz grupe atopičara i kod 10\% klinički zdravih pasa.Kod pasa koji su pokazali pozitivnu reakciju na intradermalnom testu na polen ambrozije, sekundarne lezije kože su se najčešće javljale na šapama i oko usana. Kod $88 \%$ ovih pasa na koži je u povećanom broju dijagnostikovana Malassezia pachydermatis, a kod 64\% jedinki je registrovan otitis externa različite etiologije.

$\mathrm{Na}$ osnovu dobijenih rezultata se može zaključiti da je alergen biljke Ambrosia artemisiifolia veoma značajan u indukciji atopijskog dermatitisa kod populacije pasa sa šireg područja Beograda. 